\title{
Design-Based Research
}

- introduktion til en forskningsmetode i udvikling af nye E-læringskoncepter og didaktisk design medieret af digitale teknologier

\section{Ove Christensen}

Konsulent for undervisningsdesigns

MA in History of Ideas, University College Sjælland

\section{Karsten Gynther}

Videncenterleder

Cand. pæd., University College Sjælland

\section{Trine Brun Petersen}

Projektleder

Ph.d., University College Sjælland
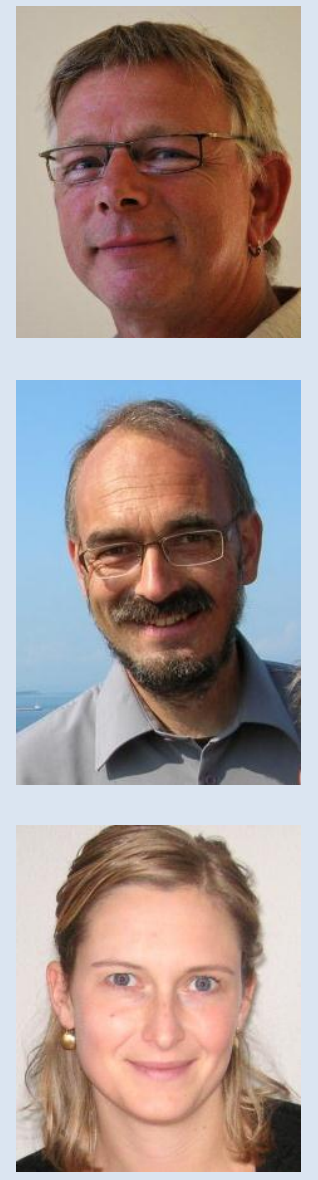

http://www.lom.dk 
Ove Christensen har tidligere undervist på Aalborg Universitet ved Institut for Kommunikation. Nu projektleder i Educationlab, hvor han faciliterer forsknings- og udviklingsprojekter inden for uddannelsesudvikling og kompetenceudvikling.

Karsten Gynther leder videncenteret Educationlab forankret i UCSJs forskningsafdeling. Videncenteret arbejder med eksperimentelle og anvendelsesorienterede forskningsprojekter relateret til udvikling af didaktisk design understøttet af nye teknologier.

Trine Brun Petersen er cand. mag og har en ph.d. i designteori og metode. Tidligere ansat på KU, Trapholt og Designskolen Kolding. $\mathrm{Nu}$ projektleder i Educationlab ved University College Sjælland.

\section{Resume}

I denne artikel introduceres forskningstraditionen Design Based Research. Artiklen præsenterer de grundlæggende antagelser, som ligger til grund for Design Based Research, og artiklen diskuterer principper for gennemførelse af et DBR-forskningsprojekt. Med udgangspunkt i forsknings- og udviklingsprojektet ELYK: E-læring, Yderområder og Klyngedannelse, præsenteres den innovationsmodel, som projektet har udviklet med udgangspunkt i Design Based Research traditionen. ELYKs DBR innovationsmodel har vist sig effektiv i forhold til projektfremdrift, brugerinvolvering og vidensgenerering, og den vil kunne inspirere andre med interesse i forskningsbaseret udvikling af didaktisk design, der er medieret af digitale teknologier.

\section{Abstract}

In this article the research methodology Design Based Research is introduced. The article presents the fundamental assumptions of Design Based Research and discusses the principles that guide the implementation of a DBR research project. Based on the research and development project ELYK: E-learning, Rural Areas and Clustering, an innovation model, which has been developed from Design Based Research principles, is presented. The DBR innovation model of ELYK has shown itself effective in assuring momentum, user 
involvement and knowledge production. It is our conviction that it will be able to inspire others with interest in research-based development of new IT didactic designs as it has inspired us.

\section{Baggrund}

I dette nr. af LOM præsenteres i en række artikler resultater fra forskningsog udviklingsprojektet ELYK. ELYK projektet handler om forskningsbaseret brugerdreven udvikling af nye e-læringskoncepter til uddannelsesinstitutioner og virksomheder i yderkanterne i Danmark. Bag projektet står et partnerskab mellem University College Sjælland (projektleder), Roskilde Universitet, Syddansk Universitet og University College Syddanmark. ELYK-projektet har metodisk været inspireret af et bredt felt af brugerinddragende udviklingsmetoder. Design Based Research (DBR) har i flere delprojekter været det grundlæggende forskningsparadigme, og ELYK-projektet har med udgangspunkt i DBRtraditionen udviklet en innovationsmodel, som har vist sig at være så udbytterig, at vi vurderer, at den vil kunne inspirere andre med interesse for forskning i og udvikling af didaktisk design medieret af digitale teknologier. Design Based Research er både internationalt og i Danmark på vej frem, og der er flere danske forskningsmiljøer, som arbejder med udgangspunkt i denne tradition, ligesom der i disse år er flere ph.d.projekter på vej, som også metodisk tager udgangspunkt i dette forskningsparadigme. Der findes dog kun meget få introduktioner til Design Based Research på dansk (se evt. Kahr-Højland 2009, Misfeldt 2010).

\section{Introduktion til Design Based Research}

Design-Based Research (DBR) er en bred forskningstilgang initieret af bl.a. Ann Brown (1992) og Allan Collins (1992). Design-Based Research (også kaldet Design Research eller Design Eksperiment) er forskning, der er designbaseret. At forskningen er designbaseret betyder inden for DBRtilgangen, at ny viden genereres gennem processer, som samtidig udvikler, afprøver og forbedrer et design. Den type af design, som DBR-projekter arbejder med, er "uddannelsesdesign" (Akker, 2006), "didaktisk design" (Andreasen, 2008) eller "læringsdesign" (Wenger, 2004), og designprocessen karakteriserer den formgivningsproces, det er at udvikle, afprøve og forbedre et læringsmiljø. Designbegrebet i Design-Based Research kan i den forstand defineres som "en systematisk, planlagt og gennemtænkt kolonisering af tid og rum i et foretagenes tjeneste" (Wenger, 2004 s. 258), hvor dette "foretagende" f.eks. er en uddannelsesinstitution eller en virksomhed. At udvikle et nyt design til et læringsmiljø kan derfor indeholde udvikling af nye artefakter, men det kan også handle om udvikling af nye måder at anvende kendte artefakter på, hvilket er et 
orienteringspunkt for ELYK-projektet, som har udviklet nye elæringskoncepter med inddragelse af forholdsvis billige og lettilgængelige hverdagsteknologier.

\section{Grundlæggende antagelser i DBR}

Design- Based research er en bred vifte af tilgange, der har en række grundlægende antagelser til fælles:

\section{Konteksten har en betydning for læring}

De fleste læringsteoretikere i dag er enige om, at konteksten har betydning for en læreproces (Lave og Wenger, 2003). Denne grundlæggende antagelse betyder, at forskning i kompetenceudvikling i såvel uddannelsessammenhænge som i arbejdet ikke kan foregå i et isoleret laboratorium. Læreprocesser skal studeres i den kontekst, de finder sted.

Der findes mange andre forskningstilgange, som også har fokus på kontekstens betydning for læring f.eks. den etnografiske forskning. DBR anvender også etnografiske metoder til at tilvejebringe domænespecifik viden om en given kontekst og til at belyse specifikke problemer i samme kontekst. Desuden anvendes etnografiske metoder til at indsamle og dokumentere anvendelsen af et givent design i praksis med henblik på analyse og forbedring. Men etnografien er i et DBR perspektiv en forståelsesorienteret forskningstilgang, som ikke direkte i selve forskningsprocessen har en intention om at ændre/forbedre praksis. Et særkende ved DBR er udvikling og afprøvning af nye designs i praksis med det ovenfor beskrevne dobbelte mål at forstå og udvikle praksis.

\section{Forståelse og forandring er to sider af samme sag}

"Hvis du ønsker at forandre noget, så må du forstå det, og hvis du ønsker at forstå noget, så må du ændre det" (Gravemeijer \& Coop, 2006, s 17).

Design-Based Research etablerer ikke det klassiske skel mellem forskning og udvikling. I stedet skelner man mellem forskningstilgange, som a) $ø$ nsker at forstå et fænomen og b) forsøger på en gang at forstå og forbedre et fænomen. DBR vil både forstå og bidrage til forbedringer af en konkret uddannelsespraksis.

\section{Intervention i praksis kan levere såvel forståelse som forbedring} DBR intervenerer i praksis, hvilket vil sige, at der udvikles nye (didaktiske) designs, som efterfølgende afprøves i en praksiskontekst, og det er en af de grundlæggende antagelser i BBR, at kun ved at intervenere med nye designs kan vi udvikle bedre teorier om praksis samtidig med, at vi forsøger at forbedre praksis. 
Deltagere fra praksis er værdifulde, uomgængelige partnere Det er ikke muligt at forstå og samtidig forbedre konkret uddannelsespraksis uden, at den viden, som deltagerne fra praksis besidder, făr en meget tydelig stemme i et konkret projekt. Det er derfor helt afgørende i et DBR-projekt at inddrage deltagerne i såvel problemidentifikation, formulering af løsningsforslag, afprøvning og forbedring af de forslåede løsninger.

\section{Principper for Design-Based Research projekter}

Ovenstående grundlæggende antagelser fører frem til en række forskningsprincipper, der både kan karakterisere og guide Design-Based Research (Cobb, 2003, Amiel \& Reeves, 2008).

- DBR er intervenerede i praksis

- DBR består af iterative processer i form af designafprøvning, evaluering, analyse og forbedring

- DBR er kollaborativ

- DBR er teoriorienteret

- DBR er pragmatisk og anvendelsesorienteret

\section{DBR er intervenerende i praksis}

DBR intervenerer i praksis med nye designs, som afprøves i en konkret praksissituation. Designorienteringen betyder, at udvikling og afprøvning af "prototyper" bliver et centralt fokus i et DBR-projekt. Prototyping er den proces, hvor designs udvikles, evalueres og forbedres gennem en systematisk proces. Prototypeafprøvningen foregår altid i en praksiskontekst. De første prototyper til et nyt koncept for læring er blot et første udkast, som måske kun demonstrerer de grundlæggende principper i konceptet. Men efterhånden udvikles prototyperne til delvise eller fuldt udviklede designs i form af konkrete anvendelige læringskoncepter / designs for læring.

\section{Designprocessen er iterativ}

Design-eksperimenter handler ikke blot om at teste om noget virker selvom det selvfølgelig er en del af processen. Det handler heller ikke om at forsøge at "bevise", at de designprincipper, som ligger til grund for et givent design, er "sande". Design-eksperimenter består af iterative forløb, som tester og forbedrer designet i praksis med det formål, at de udviklede designs kan blive så robuste, at de kan anvendes i forskellige kontekster (diSessa \& Cobb, 2004).

Evalueringsforskning og andre typer af følgeforskning evaluerer ligesom DBR også forskellige typer af interventioner. Men målet med evalueringsforskning er forståelse, vurdering og evt. anbefalinger ud fra en given norm. DBR anvender metoder fra evalueringsforskningen, men med http://www.lom.dk 
det specifikke formål at forbedre og efterfølgende igen afprøve, evaluere og videreudvikle et design (Barab \& Squire, 2004).

Det er vigtigt at understrege, at forskningsprocessen er iterativ, hvilket betyder, at man ikke kun evaluerer en intervention, men systematisk forsøger at forbedre designet, mens man samtidig producerer designprincipper, der kan guide lignende forskning (Amiel \& Reeves, 2008).

Udvikling af designprincipper vil forløbe som en serie af forløb i form af test og forbedringer. Det er vigtigt løbende at indsamle data med henblik på at kunne redefinere problemer, mulige løsninger og de principper, som ligger bag en foreslået løsning. Analyser og refleksion over data anvendes til at skabe nye designs, som efterfølgende igen afprøves, evalueres, analyseres og re-designes.

Evaluering af et design handler om at forbedre; ikke at bevise kvaliteten af en prototype. Evalueringen handler om at undersøge om designet er gennemførligt i en hverdagspraksis, om det er relevant for deltagerne at bruge, om designet bevarer sin legitimitet i forhold til deltagernes artikulerede krav til designet og om det er effektivt i forhold til tid, økonomi, oplæringstærskel mv. (Mckenney-et al., 2006).

Analysen i en iterativ proces handler om at lukke gabet mellem det intenderede, det implementerede og det realiserede design. Dette er kendt fra læseplansforskning. Der kan være stor forskel på intentionen med et læringskoncept, det konkrete koncept med valg af værktøjer og procedurer, som det præsenteres for deltagerne, og endelig den måde deltagerne anvender et givent koncept på. Analyse i en iterativ proces handler om at generere viden, som kan bidrage til at mindske forskellen mellem de tre designniveauer (Mckenney et al., 2006).

\section{DBR er kollaborativ}

Den grundlæggende antagelse, at deltagere fra praksis er værdifulde og nødvendige partnere i et DBR-projekt, får store konsekvenser for planlægning og gennemførelse af et DBR-projekt. Samarbejdet med deltagere fra praksis er nødvendigt med henblik på problemidentifikation, i arbejdet med at finde de karakteristiske træk ved en potentiel løsning, samt når man iterativt afprøver og forbedrer en intervention. Det kan her være et meget tidskrævende arbejde at finde deltagere, der vil medvirke i et projekt, "forhandle" sig frem til et projekt, der har fælles interesse og ikke mindst opbygge en tillidsfuld relation til deltagerne. Helt konkret kræver det, at forskerne må vise engagement og tilstedeværelse i alle projektets faser, ligesom det er vigtigt at anerkende deltagernes bidrag $\mathrm{i}$ innovationsprocessen. At gennemføre et designeksperiment kræver derfor 
både styring fra forskerside og tid og vilje til at opbygge et fortløbende fællesskab med deltagerne fra praksis (Cobb et al., 2003,Amiel \& Reeves, 2008).

DBR har her mange fælles træk med aktionsforskning og henter også inspiration fra denne forskningstilgang, men DBR adskiller sig på enkelte områder fra aktionsforskning. Aktionsforskning etablerer også et samarbejde mellem forskere og deltagere, er forankret i praksis, arbejder systematisk med teori og har som mål at forbedre såvel teori som praksis. Men lokale forbedringer er typisk initieret af deltagernes egne undersøgelser, som er faciliteret af forskere. I DBR er det forskere og deltagere fra praksis som i fællesskab identificerer problemer fra praksis og udvikler forslag til innovation af ny praksis (Wang \& Hannafin, 2005). Det er i et DBR projekt også legitimt og en del af forsknings- og udviklingsprocessen, at forskerne kommer med innovationsforslag (i form af prototyper til nye designs), der videreudvikles i et samarbejde med deltagere fra praksis. Forskerrollen som "ekspert" er derfor tydeligere i et DBR projekt end i et aktionsforskningsprojekt.

\section{DBR er teoriorienteret}

De designs, som udvikles i et DBR-projekt, er funderet på - i hvert fald delvist - nogle teoretiske positioner (designteorier), ligesom afprøvningen af et givet design bidrager til teoriudvikling. DBR har derfor altid som mål både at forbedre teori og praksis (The Design-Based Research Collective, 2003). Designeksperimenter udføres for at udvikle teorier; ikke bare for at optimere en praksis. Designeksperimenter handler derfor ikke om at demonstrere, at et givent design eller en given læringsteori virker i praksis. Formålet er at videreudvikle de teorier, som lå bag designet. Målet er at udvikle designteorier, der forklarer, hvorfor noget virker, og hvordan det måske vil blive adapteret i nye kontekster.

At et DBR-projekt skal være funderet på teoretisk indsigt, andre forskningsresultater mv. har også en pragmatisk begrundelse. DBR er udforskende og forsøger at være problemløsende. Et DBR projekt tager udgangspunkt i den grundlæggende forestilling, at en eksisterende praksis kan forbedres. DBR indeholder en innovationsdimension. Her må man balancere mellem et ønske om innovation og risikoen for at udvikle noget, som slet ikke fungerer eller er spild af ressourcer for deltagere fra praksis, forskere samt andre interessenter. Når man i et DBR-projekt udvikler designs på grundlag af eksisterende teori og anden forskning handler det også om at minimere risikoen for spekulative projekter. Designs skal være funderet på teori og på en grundig analyse af praksis, idet det alt andet lige øger chancen for udvikling af realiserbare, legitime og effektive designs (Edelson, 2006). 
Designeksperimenter etablerer mulighed for teoriudvikling med udgangspunkt i praksis, hvilket også kendes fra forskningstilgangen "Grounded Theory" (Glaser og Anselm 1967). De teorier som udvikles gennem et designeksperiment er tæt bundet til en konkret praksis. Teoriudvikling "must do real work" (Coob et al., 2003). De udviklede teorier må direkte adressere de problemer, som praktikere oplever i deres daglige arbejde, og værdien af teori afhænger derfor af, hvordan principper og teorikoncepter kan informere og forbedre praksis. Teorierne skal have et praktisk anvendelsespotentiale, idet de skal bidrage til løsning af problemer i praksis, og de kan derfor ikke genereres isoleret fra praksis eller gennem mere traditionelle empiriske tilgange.

Det betyder, at den teoretiske orientering i DBR ikke så meget handler om de store teorier, men mere om domænespecifikke teorier om læring i en given kontekst samt designteori. Målet er at udvikle designteorier, som forklarer, hvorfor noget virker i specifik kontekst, og hvordan det måske vil blive adapteret i nye kontekster. "De store teorier", overordnede læringsteoretiske eller didaktiske rammeforståelser og fagdidaktiske metoder, er udmærkede udgangspunkter, men de er ikke tilstrækkelige som basis for gennemførelse af et designeksperiment (diSessa et al. Cobb, 2004).

Der findes tre typer af teorier, som er relevante i et DBR-projekt (Edelson, 2006):

- Domænespecifikke teorier

- Design framework

- Design-metodologier

Domænespecifikke teorier er deskriptive teorier, som forholder sig til kernen i det problem, man arbejder med. De er ikke såkaldte "store teorier", men netop rettet mod et specifikt domæne. Design framework og design metodologier er præskriptive. Designframework er en generaliseret designløsning (f.eks. et bud på et læringskoncept), der bygger på nogle designprincipper, som udspringer af de domænespecifikke teorier, der konkret arbejdes med, og som formodes at kunne bidrage til at løse et givent problem. Design-metodologier er procedurer, som guider processen frem mod udviklingen af et givent design og ny viden. Det er procesprincipper, for hvordan designet udvikles og testes.

Et eksempel på sidstnævnte er Knutsson mfl.s workshopmodel. Her anvender man i designudviklingsfasen (udviklingen af prototypen) en fremadskridende workshopmodel med tre forskellige workshops, hvor forskere og deltagere fra praksis i fællesskab udvikler den første prototype for et nyt design (Knutsson et al., 2010) I workshop nr. 1 valideres den http://www.lom.dk 
indledende problemidentifikation, hvilket følges op med en ide-generering af mulige løsningsforslag. Mellem workshop 1 og 2 udvælger forskere og teknologieksperter de designs, som ud fra en række kriterier er mest lovende (realiserbarhed, legitimitet, effektivitet). Derefter afholdes workshop nr. 2 med deltagere fra praksis. Her forsøger man i fællesskab at kvalificere de ideer til koncepter, som er i spil. Mellem workshop 2 og 3 udvikles den allerførste prototype. Afhængig af om der er udviklet en mock up eller en prototype med en vis funktionalitet, vil workshoppen enten kvalificere mock up'en eller lave de første oplærings- og afprøvninger af funktionalitet mv. i den udviklede prototype.

\section{Teorigenerering og generalisering}

Lokal nytteværdi er nødvendig men ikke tilstrækkelig i et DBR-projekt. DBR-eksperimenter må lede til teoretiske udsagn, som overskrider den lokale kontekst og et specifikt design. I et formidlingsperspektiv betyder dette, at det ikke er nok blot at sprede et godt design. Man må også skabe fyldige beskrivelser af den givne kontekst designet er udviklet i. Det konkrete designeksperiment må analyseres med henblik på at identificere generaliseringer, som kan udtrykkes i form af domænespecifikke teorier, designframework og designmetodologier, som kan anvendes af andre.

DBR fokuserer på at forstå kompleksiteten i praksis. Et af problemerne i DBR er at karakterisere kompleksiteten, soliditeten og evt. skrøbeligheden af et design på en måde, som kan være værdifuld for andre. Det betyder, at DBR ikke blot skal forstå, hvad der sker i en bestemt kontekst, men også vise relevansen af en intervention i en kontekst for andre kontekster.

\section{DBR er anvendelsesorienteret}

DBR er anvendelsesorienteret (Cobb et al., 2003), hvilket tydeligt fremgår af en række af ovenstående principper. Men anvendelsesorienteringen er ikke det primære kendetegn ved DBR-projekter. DBR er en pragmatisk forskningstilgang, som har en intention om at medvirke til at forbedre eksisterende uddannelsespraksis, og den fokuserer derfor direkte på konkrete problemer fra praksis. Men orienteringen mod teori er stadig det dominerende perspektiv i et DBR-projekt. Så selvom anvendelsesorienteringen, ønsket om innovation og involvering af konkrete brugere fra praksis, er fælles træk mellem DBR og brugerdrevne innovationsprocesser, så er det teoriorienteringen, som adskiller de to typer af tilgange.

\section{Hvordan udføres et DBR projekt?}

Da DBR er en bred forskningstilgang og ikke en systematisk metode, findes der mange forskellige fasemodeller og mere konkrete metodiske principper, man konkret kan anvende. Den DBR-fasemodel, som ligger tættest på den måde, vi har anvendt i flere af ELYK-projekterne, er http://www.lom.dk 
udarbejdet af Thomas Reeves (Reeves, 2006, Amiel \& Reeves, 2008). Reeves model er en firefaset forskningsmodel med følgende faser:

Fase 1: Problemidentifikation (foretaget af forskere og praksisdeltagere i fællesskab, som analyser af problemer i en given praksis)

Fase 2: Udvikling af løsningsforslag (med udgangspunkt i eksisterende designprincipper og teknologiske innovationer)

Fase 3: Iterative forløb (af test i praksis og forbedring af designs)

Fase 4: Refleksion (med henblik på at producere "designprincipper" og forstærke implementeringsmulighederne)

Med inspiration fra ovenstående firefasede model har vi i ELYK-projektet udviklet en innovationsmodel, som strukturerer fire forskellige typer af forskningsopgaver i et DBR projekt. Hver type har et bestemt mål og en række tilknyttede unikke metoder. Selvom forskningsprocessen er iterativ også mellem de forskellige opgavetyper indikerer modellen også en progression i et DBR-projekt. Som sådan er innovationsmodellen også en fasemodel. I modelform kan opgavetyper, mål og metoder illustreres på nedenstående måde. 


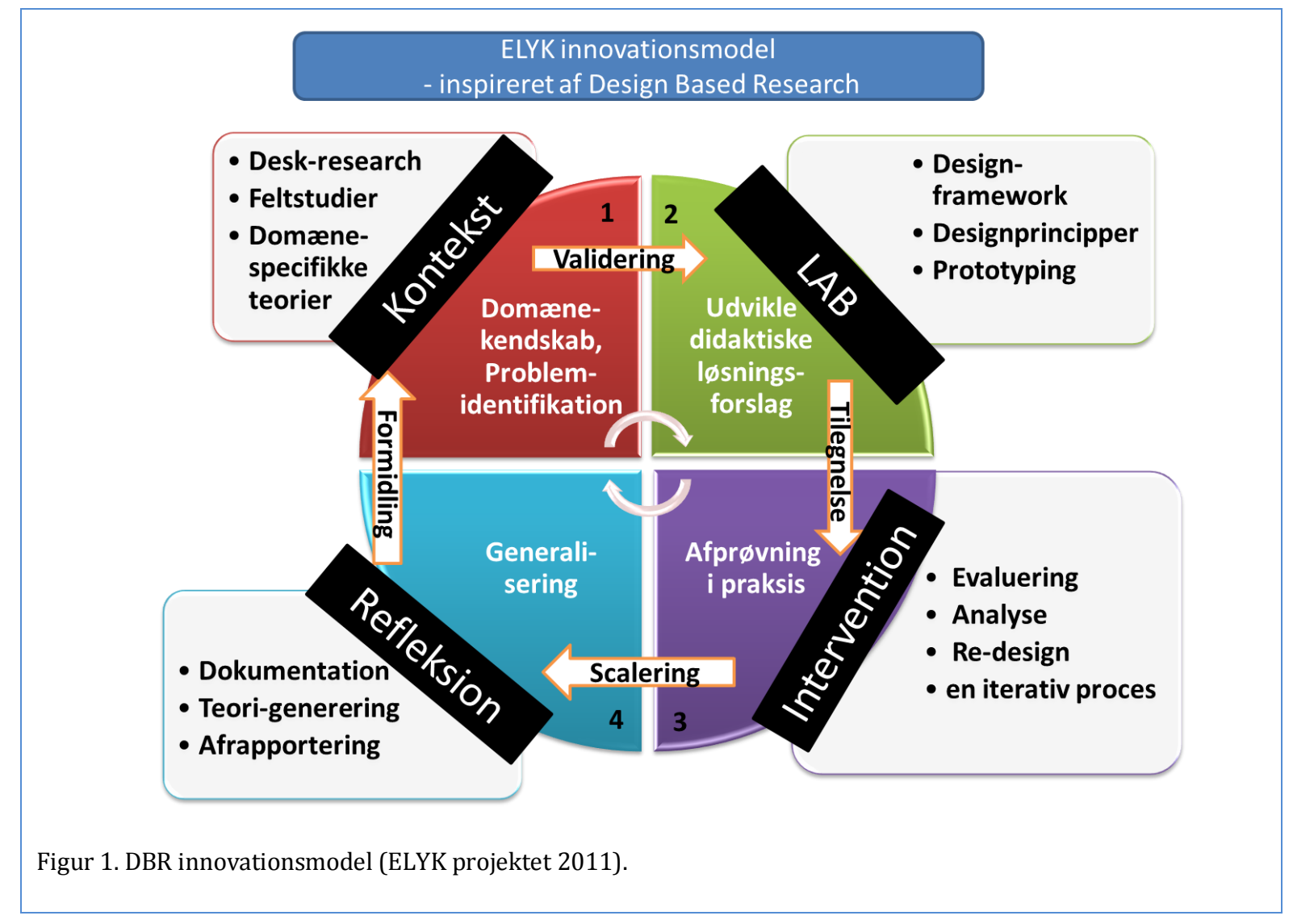

Konteksten: Kontekstanalyse og problemidentifikation

Et DBR-projekt starter altid med en kortlægning og analyse af identificerbare problemer i en given læringskontekst, hvad enten den er formaliseret i et uddannelsessystem eller er en del af læringsmiljøet på en arbejdsplads. I stedet for begrebet "problemidentifikation", som anvendes i DBR-traditionen, har vi i nogle sammenhænge i stedet anvendt termen "identifikation af innovationspotentiale". Det er vores erfaring, at det at tale om innovationspotentialer i stedet for identifikation af problemer i højere grad motiverer deltagerne fra praksis til at deltage i et forsknings- og udviklingsprojekt, som skal innovere deres praksis.

Mange DBR-projekter starter i fase 1 med at lave desk-research med henblik på problemidentifikation, og resultaterne herfra drøftes med deltagere fra praksis. I ELYK-projekterne supplerede vi i fase 1 deskresearch med forskellige former for feltarbejde i konkrete kontekster bl.a. inspireret af etnografiske tilgange. Forskellige former for observation, interviews, dokumentanalyse og videooptagelse anvendtes til at få en domænespecifik viden om en konkret kontekst og samtidig identificere evt. problemer i eksisterende praksis. Domænespecifikke teorier bringes i spil til at fortolke det empiriske materiale. 
I dette nr. af LOM er flere af artiklerne udsprunget af ELYK projektet, og i disse artikler demonstreres den empiriske anvendelse af ELYK innovationsmodellen. Forfatterne til denne artikel har bl.a. deltaget $\mathrm{i}$ udviklingen af en digital patientmappe til fysioterapeutisk praksis, et projekt som er beskrevet mere udførligt i en særskilt artikel i dette nr. af LOM. Her redegør vi for, hvordan vi i innovationsmodellens fase 1 er startet med at lave større desk-research, hvor vi har bl.a. har screenet anden forskning på området, analyseret historiske dokumenter fra fysioterapeuternes fagblad samt analyseret interviews med en række nøgleaktører inden for uddannelsen til fysioterapeut med henblik på at generere domænespecifik viden om den udvikling, som professionen fysioterapeut har gennemløbet de sidste årtier. Jf. fase $1 \mathrm{i}$ modellen er dette efterfølgende blevet fulgt op med feltstudier, hvor vi både har observeret, videofilmet og interviewet fysioterapeuter i forbindelse med deres daglige arbejde. I en fælles analyse med fysioterapeuterne var det efterfølgende muligt at udpege en række problemer i den eksisterende praksis. Det handlede i særlig grad om den kommunikative praksis mellem fysioterapeut og patient, som i en lang række tilfælde ikke blev fastholdt (tingsliggjort) i et lagermedie og ej heller blev gjort tilgængelig for patienterne efter konsultationen. Analyser af videooptagelser fra konsultationen viste, at konsekvensen af dette var, at en del patienter ikke kunne huske, hvad deres diagnose gik ud på - hvilket forhandlingsforløb, der var aftalt, samt hvilke typer af øvelser patienterne skulle lave hjemme.

\section{Lab: Udvikle didaktiske løsningsforslag}

I fase 2 arbejdede vi med forskellige metoder, som kan involvere deltagere fra praksis i validering af problemidentifikationen og understøtte en fælles ide-generering af løsningsforslag. (Jf. ovenstående trefasede workshopmodel). I Lab-fasen af et DBR-projekt kombineres domænespecifik viden med designframework og designprincipper, og med udgangspunkt i en designmetodologi udvikles den første prototype sammen med deltagere fra praksis. I eksemplet med den digitale patientmappe udviklede en gruppe fysioterapeuter og os en række principper til forbedring af den didaktiske kommunikation mellem fysioterapeuter og patienter, og igennem et forløb over tre workshop blev den første prototype for en webbaseret mappe, som kunne fastholde kommunikationen, udviklet.

\section{Intervention: Afprøvning i praksis og evaluering, analyse og forbedring af designs}

Når den første prototype er udviklet i et "lab" dvs. på en eller flere typer af workshops, er fokus herefter på eksperimenter i virkelige kontekster med alle de variable, som kendetegner praksis. En første fase er her ofte en tilegnelsesfase, hvor deltagerne fra praksis lærer at håndtere såvel 
teknologi som nye arbejdsorganiserende principper gennem kurser, sparing mv. Herefter kan designeksperimentet begynde.

Et designeksperiment foregår altid i en virkelig kontekst med alt, hvad det medfører. De overordnede faser er fælles i alle typer af designeksperimenter og foregår i det ovenfor beskrevne iterative forløb: Design afprøves i praksis, designet evalueres, designet analyseres og designet redesignes (Mckenney, Susan et al., 2006). Eksperimentet udføres med sædvanlige videnskabelige standarder og dokumenteres løbende. Designet udvikler sig løbende, dvs. prototypen går fra at være en skitse til et koncept, til at være en delvis løsning og i bedste fald blive et fuldt fungerende læringskoncept.

Eksperimentet følges igen af feltforskning, og evalueringen har øje for, om brugen af designet er realiserbart, legitimt og effektivt (Mckenney, Susan et al. 2006). Evalueringen må selvfølgelig have øje for alle de kontekstfaktorer, som har betydning for, om intentionerne i et design kan realiseres. Kontekst er aldrig uden aktører. Der er altid teknologier, lærere, administratorer, studenter og andre medlemmer af et læringsmiljø, som skaber konteksten, og derfor skal en designteori medtænke disse aktører. Det er derfor vigtigt at dokumentere sammenhængen mellem kontekst og brugen af et konkret design.

Det er bl.a. vigtigt at have øje for følgende kontekstfaktorer (Collins, Allan et al., 2004):

- $\quad$ Setting (hvor er vi - skole/arbejdsplads/museum mv.)

- Læringsklima / læringsmiljø (engagement, samarbejde, innovationslyst, autonomi for deltagerne)

- Deltagerforudsætninger (alder, socioøkomisk status mv.)

- Videns- og læringsvariable (hvad skal læres? Læringsstrategier mv.)

- Nødvendige ressourcer og support i implementeringsfasen

- Professionsudvikling (Sværhedsgrad/kompetenceudvikling i form af kurser, workshops mv.)

- Ressourceforbrug (tid, økonomi, teknologi mv.)

- Implementeringsstrategi (hvordan introduceres designet i hvilken rækkefølge og hvilke elementer introduceres hvornår?)

Hvis man kun fokuser på et mindre delsystem (f.eks. en klasse) uden at forstå, at klassen er del af et større subsystem (skolen), som igen er en del af hele uddannelsessystemet, vil man ikke kunne forstå, hvorfor et design ikke virker uden for den lokale afprøvning/setting. Analysen af en given intervention må derfor også belyse betydningen af de overordnede rammer, som en given kontekst er indlejret i. Det kan f.eks. være mere overordnede politiske, administrative og økonomiske forhold, som en http://www.lom.dk 
given praksis er en del af. F.eks. er det ofte ikke muligt at innovere et læringsmiljø (f.eks. en undervisningssituation), hvis den læringskultur, som undervisningen er en del af, ikke er interesseret i innovationen (Collins, Allan et al. 2004).

Evalueringen skal give de nødvendige input til analysen, som har fokus på, hvordan man kan mindske forskellen mellem det intenderede design, det implementerede design og det realiserede design. Denne analyse fører så frem til en designrevidering, og det iterative forløb gentages.

I eksemplet med den digitale patientmappe resulterede denne iterative proces i en række ændringer af den oprindelige prototype, som var udviklet i fase 2 af forløbet. Praksiseksperimenterne viste hurtigt, at kun en meget enkel og let tilgængelig løsning ville kunne integreres i det daglige arbejde, idet de private klinikker grundet deres økonomiske vilkår kun kunne få gavn af en løsning, som kunne integreres uden ekstra tidsforbrug i den behandlingspraksis, der allerede var etableret. Løsningen herpå blev anvendelsen af de kendte delingsværktøjer i mobiltelefoner, hvor man med et enkelt klik kan dele informationer i form af video, billeder eller lyd med andre. Fysioterapeuterne kunne nu i en og samlet handling optage f.eks. en video af en øvelsesinstruktion med patienten og med et klik dele den i en i forvejen oprettet webbaseret mappe, som var fælles for patient og fysioterapeut. En anden iteration havde fokus på den device, som blev anvendt til denne proces. I de første eksperimenter anvendte vi en mobiltelefon, men der opstod hurtigt et behov for, at fysioterapeut og patient under konsultationen begge kunne se og drøfte, det som blev optaget på f.eks. en video. Da skærmformatet på en mobiltelefon var for lille til dette, blev prototypen ændret, og vi begyndte at arbejde med tabletformatet i stedet.

\section{Refleksion: Generalisering}

Generaliseringen handler om at afgøre, hvor robust designet er i forhold til forskellige typer af kontekster. Det betyder, at formålet med et DBR projektet ikke blot er at forstå, hvad der sker i en bestemt kontekst, men også vise relevansen af en intervention i for andre kontekster.

DBR er primært orienteret mod formative evalueringer af designs med henblik på revision/forbedring, men ved afslutningen af et DBR-projekt er det vigtigt også at lave en summativ evaluering, der overvejer opskaleringsmulighederne og evaluering af, om et design kan transformeres til andre, men lignende kontekster. Det er her særligt vigtigt at reflektere over Hawthorne-effekten (Landsberger, 1958) og betydningen af, at forskeren har haft to forskellige roller, idet han/hun har været både intervenerende og evaluerende. 
I forhold til skalering kan man skelne mellem tre forskellige typer af afprøvninger (Mckenney et al., 2006):

Alfa afprøvning: Konteksten er ideel og forsøgt kontrolleret af forskerne.

Beta afprøvning: Konteksten er nøje udvalgt og tilbydes support.

Gamma afprøvning: Har fokus på spredning i stor skala med minimal support.

I eksemplet med den digitale patientmappe anvendte vi opskalering som metode til at få information om, hvor robust den udviklede digitale patientmappe var, idet vi i de tre første faser i ELYK innovationsmodellen samarbejdede med tre private klinikker, mens vi i fase fire i modellen involverede en række nye klinikker, som ikke havde været den del af selve udviklingsfasen.

Erfaringerne fra alle de deltagende klinikker blev efterfølgende inddraget $\mathrm{i}$ en systematisk refleksion med udgangspunkt bl.a. dokumentation af processen og specificering af de anvendte designprincipper og deres relation til det overordnede framework, der lå til grund for designet. Udbyttet af denne type af refleksion vil være nogle designprincipper eller guidelines, der er empirisk funderet og udførligt beskrevet, og som kan implementeres af andre, der arbejder med lignende problemstillinger. Samtidig skal den systematiske dokumentation og refleksion afrapporteres til stakeholders og transformeres til forskellige former for formidling af projektresultater tilbage til praksis.

\section{Et kritisk perspektiv på Design Based Research i ELYK} projektsammenhæeng

I ELYK projektet har vi forholdt os til en række af de udfordringer - nogle ville kalde det kritikpunkter - som man støder ind i, når man gennemfører et DBR projekt. Den første udfordring er forholdet mellem forskningsinteressen og udviklingsinteressen. I ELYK projektet har vi forsket gennem udviklingsprocesser og udviklet gennem forskningsprocessen, men da projektet har fået midler til netop at innovere eksisterende uddannelsespraksis kan man sige, at dette normative grundvilkår kan betyde, at et projekt som ELYK nemt kan tippe over og blive et rent udviklingsprojekt. Her er det vigtigt at holde fast $i$, at DBR forskning både vil udvikle og generere forståelse, og et af DBR principperne er netop, at dette er to sider af samme sag. I ELYK projektet har vi da også været inspireret af diskussionen om "anvendt forskning" (Stoke, 1973) og Ib Ravns overvejelser vedr. "transformativ forskning" (Ravn, 2010), men forholder man sig snævert til DBR tilgangen er der ingen tvivl. Formålet 
med DBR forskning er helt overordnet teoriudvikling og her kommer udviklingsinteressen i anden række.

En anden udfordring i DBR forskning er forskerrollen, idet man som DBRforsker både er "forsker" og "designer". Som forsker har du både interesse i at udvikle ny forståelse, men samtidig er du også dybt involveret i at designe en ny praksis eller et artefakt, som kan indgå i udviklingen af et nyt didaktisk design. Denne udfordring diskuteres grundigt i artiklen "Balancing Product Design and Theoretical Insights" (Ejersbo mfl. 2008), som i deres artikel udvikler en model, der beskriver to parallelle processer, som guider henholdsvis forskerrollen og designerrollen. Udgangspunktet for begge roller er en problemstilling fra praksis. Designerrollen arbejder her i faserne: problem, design, intervention og endeligt artefakt (som kan tilbydes praksis/markedet) mens forskerrollen arbejder parallelt med faserne: problem, hypotese, data og teoriudvikling (hvor sidstnævntes kvalitet kan vurderes af fagfæller).

En tredje udfordring i et DBR projekt er generaliseringsproblemet. Spørgsmålet er om de udviklede nye didaktiske designs (og dermed den teori, som er udviklet sammen med) kun er gældende for præcis den kontekst, de er udviklet i. Hermed berører vi samtidig diskussionen mellem kvalitativ og kvantitativ forskning, hvilket ikke ligger inden for omfanget af denne artikel at diskutere. Inden for DBR forskningskredse diskuteres generaliseringsproblemet intenst, og det foreløbige svar på denne udfordring er som tidligere nævnt $i$ artiklen enten meget deltaljerede beskrivelser (thick description) af de kontekster koncepterne er udviklet i og/eller opskalering til nye kontekster. Hermed også sagt, at et DBR resultat ikke kan generaliseres til en større population som sådan, men det er muligt at udtale sig om graden af "robusthed" for et givent koncept, ligesom de deltaljerede beskrivelser giver eksterne interessenter mulighed for at vurdere om et givent koncept kan overføres til den kontekst interessenterne repræsenterer.

Den sidste udfordring - som måske snarere er en præcisering - er spørgsmålet om brugerinvolvering, brugerdeltagelse og brugerorientering i DBR traditionen. I ELYK projektet har vi været inspireret af både DBR, brugerdreven innovation samt aktionsforskning (Lewin 1946, Nielsen 2004). DBR og aktionsforskning er ikke det samme, og særligt i forhold til forskningsformål og forholdet til praksis er de to retninger forskellige. Gunver Majgaard mfl. peger bl.a. på følgende forskelle mellem de to tilgange (Majgaard, Misfeldt og Nielsen 2012). I forholdet mellem forskningsinteressen og praksisinteressen har DBR primært fokus på forskning, mens aktionsforskning primært har fokus på praksis. Det betyder ifølge Majgaard mfl., at DBR forskning ikke har fokus på 
empowerment og deltagernes ejerskab af processen mens "empowerment, participative users and awareness" (op. cit. S. 23) hos deltagerne fra praksis står centralt i et aktionsforskningsprojekt. Som også Majgaard mfl. viser i deres artikel kan de to tilgange meget fint supplere hinanden, hvilket vi også har gjort i ELYK projektet.

\section{Design Based Research - en af flere forskningstraditioner, som har inspireret ELYK-projektet \\ ELYK projektet er inspireret af flere forskellige forsknings- og udviklingstraditioner herunder aktionsforskning, brugerdreven innovation og Design-Based Research. Design-Based Research-tilgangen i ELYK- projektet har i særlig grad vist sin styrke på følgende områder:}

- Denne forskningstradition skelner ikke mellem et udviklingsperspektiv og et forskningsperspektiv. At forstå og forandre en praksis er to sider af samme sag, hvilket i særlig grad har matchet ELYK-projektets mål om forskningsbaseret udvikling af nye e-læringskoncepter.

- DBR-traditionens skitsering af forskellige indbyrdes forbundne forskningsopgaver og ELYK-projektets fortolkning heraf i en firefaset innovationsmodel har været en særdeles robust forsknings- og udviklingsmodel, som både har sikret fremdrift og kvalificeret vidensproduktion samtidig med, at ELYK-projektets mere normative innovationsmål aldrig er forsvundet.

- DBR-traditionens eksperimenterende og intervenerende tilgang kendes også fra andre udviklingstraditioner. Styrken ved at anvende DBR er, at eksperimenter ikke blot kobles sammen med følgeforskning. Forskerrollen er i DBR langt mere involverende end i andre deltagerorienterede metoder, og forskere og deltagere fra praksis evaluerer, analyserer og re-designer i fællesskab de designs, der er eksperimenteret med. Denne fælles iterative co-designproces mellem deltagere og forskere er efter vores erfaring en stor styrke ved DBRforskning.

- De fire faser, som er beskrevet i ELYKs innovationsmodel, findes også i mange andre udviklingsmodeller. Et DBR-projekts særlige kendetegn er kravene til dokumentation, refleksion, generalisering og dermed teorigenerering. Især kravet om, at enkeltstående eksperimenter skal opskaleres og gentages i andre kontekster med henblik på at afgøre, om de udviklede designs er så robuste, at man kan fortage forskellige former for generaliseringer, er et vigtig træk ved DBR projekter. 


\section{Referencer}

Akker, J. V. D., Gravemeijer, K., McKenney, S., \& Nieveen, N. (Eds.). (2006). Educational Design Research. London \& New York: Routledge.

Amiel, T., \& Reeves, T. (2008). Designbased research and Educational Technology: Rethinking Technology and the Research Agenda. Educational Technology \& Society, No. 11.

Andreasen, L. B., Meyer, B., \& Rattleff, P. (2008). Digitale medier og didaktisk design. København: Danmarks Pædagogiske Universitetsforlag.

Barab, S., \& Squire, K. (2004). Design-Based Research: Putting a Stake in the Ground. Journal of the Learning Sciences, 13(1), 1-14.

Brown, A. L. (1992). Design experiments: Theoretical and methodological challenges in creating complex interventions in classroom settings. Journal of the Learning Sciences, 2(22), 141-178.

Collins, A. (1992). Towards a design science of education. In E. Scanlon \& T. O'Shea (Eds.), New Directions in Educational Technology (pp. 15-22). Berlin: Springer.

Collins, A., Joseph, D., \& Bielaczyc, K. (2004). Design Research: Theoretical and Methodological Issues. Journal of the Learning Sciences, 13(1), 1542.

Confrey, P. C., diSessa, A., Lehrer, R., \& Schauble, L. (2003). Design Experiments in Educational Research. Educational Researcher, 32 (nr).

diSessa, A. A., \& Cobb, P. (2004). Ontological Innovation and the Role of Theory in Design Experiments. Journal of The Learning Sciences, 13(1), 77-103.

Edelson, D. C. (2006). What we learn when we engaged in design: Implication for assessing Design Research. In J. V. D. Akker, K. Gravemeijer, S. McKenney \& N. Nieveen (Eds.), Educational Design Research, London \& New York: Routledge.

Ejersbo, Lisser R. mfl. (2008). Balancing Product Design and Theoretical Insights. In. Kelly, Anthony mfl. (ed.). Handbook of Design Research Methods in Education. Routhledge.

ELYK projektet: www.elyk.dk 
Glaser, Barney G. and Anselm L. Strauss. (1967/ 2008): The Discovery of Grounded Theory: Strategies for Qualitative Research. New Brunswick, New Jersey: Aldine Transaction.

Gravemeijer, K., \& Coob, P. (2006). Design Research from a learning design perspective. In J. V. D. Akker, K. Gravemeijer, S. McKenney \& N. Nieveen (Eds.), Educational Design Research . London \& New York: Routledge.

Gynther, K. (2010). Brugerdreven forskningsbaseret innovation af didaktisk design - transformative metoder i forsknings- og udviklingsprojektet ELYK. Retrieved Jan 12, 2012, from http://www.elyk.dk.

Kahr-Højland, A. (2009). Læring er da ingen leg? En undersøgelse af unges oplevelser i og erfaringer med en mobilfaciliteret fortælling i en naturfaglig kontekst. Ph.d. afhandling. DREAM/SDU.

http://static.sdu.dk/mediafiles//Files/Information_til/Studerende_ved_SD U/Din_uddannelse/phd_hum/afhandlinger/2009/AKH\%20Ph\%20D\%2 0afhandling\%202009\%20\%202.pdf (hentet 12.06.12)

Knutsson, O., Nissilä, N., Carlsson, N. J., \& Räsenän, M. (2010). User-driven design of mobile application for teenagers' language homework. In T. Ceratto-Pargmann, P. Hyvönen, S. Järvelä \& M. Milrad (Eds.), The First Nordic Symposium on Technology Enhanced Learning (pp. 49-51). Växjö.

Landsberger, Henry A. (1958): Hawthorne Revisited. Ithaca, New York. Cornell University.

Lave, Jean \& Wenger, Etienne (2003). Situeret læring og andre tekster. Hans Reitzels Forlag.

Lewin, K., (1946). Action Research and Minority Problems, Journal of Social Issues. Vol. 2, No. 4, pp. 34-46.

Majgaard, Misfeldt og Nielsen (2012). How design-based research and action research contribute to the development of a new design for learning. In: Designs for learning. Vol. 2\#11 p. 8 - 27.

McKenney, S., Nieveen, N., \& Akker, J. v. d. (2006). Design Research from a Curriculum perspective. In J. V. D. Akker, K. Gravemeijer, S. McKenney \& N. Nieveen (Eds.), Educational Design Research. London \& New York: Routledge.

Misfeldt, M. (2010). 'Forestillet læringsvej' i IT-baserede pædagogiske udviklingsprojekter. Dansk Pædagogisk Tidsskrift, vol 58, nr. 4, 42-52. 
Nielsen, K. (2004). Aktionsforskningens videnskabsteori, Videnskabsteori i samfundsvidenskaberne. På tværs af fagkulturer og paradigme, Roskilde, Roskilde Universitetsforlag, 2004.

Nieveen, N., McKenney, S., \& Akker, J. v. d. (2006). Educational Design Research: The value of variety. In J. V. D. Akker, K. Gravemeijer, S. McKenney \& N. Nieveen (Eds.), Educational Design Research. London \& New York: Routledge.

Ralph, P., \& Wand, Y. (2009). A proposal for a formal definition of the design concept. In K. Lyytinen, P. Loucopoulos, J. Mylopoulos \& W. Robinson (Eds.), Design Requirements Workshop (LNBIP 14) (pp. 103136). Springer.

Reeves, T. (2006). Design Research from a Technology perspective. In J. V. D. Akker, K. Gravemeijer, S. McKenney \& N. Nieveen (Eds.), Educational Design Research. London \& New York: Routledge.

Stokes, Donald E. (1997): Basic Science and Technological Innovation. Washington, Brookings Institution Press

Ravn, Ib (2010): 'Transformative forskningsmetode - belyst gennem et projekt om mødefacilitering'. In: Tidsskrift for arbejdsliv, 12 årg. nr. 1.

The design-based Research Collective. (2003). Design- Based Research: An Emerging paradigm for Educational Inquiry. Educational Researcher, 32(1), 5-8.

Walker, D. (2006). Towards productive design studies. In J. V. D. Akker, K. Gravemeijer, S. McKenney \& N. Nieveen (Eds.), Educational Design Research . London \& New York: Routledge.

Wang, F., \& Hannafin, M. (2005). Design-based research and technology enhanced learning environments. Educational Technology, Research and Development, 53(4), 5-23.

Wenger, E. (2004). Praksisfællesskaber. København: Hans Reitzel. 